Payne, W. N. (1952). Arch. Dis. Childh. 27, 302.

Quarterman, J., Dalgarno, A. C. \& Adam, A. (1963). Biochem. \%. 86, IP.

Rhaney, K. \& Mitchell, R. G. (1956). Lancet, i, 1028.

Schlesinger, B. E., Butler, N. R. \& Black, J. A. (1956). Brit. med. F. i, I 27.

Smith, D. W., Blizzard, R. M. \& Harrison, H. E. (1959). Pediatrics, Springfield, 24, 258.

Stapleton, T., Macdonald, W. B. \& Lightwood, R. (1956). Lancet, i, 932.

Thomas, W. C., Morgan, H. G., Connor, T. B., Haddock, L., Bills, C. E. \& Howard, J. E. (I959). F. clin. Invest. $\mathbf{3}^{8}, 1078$.

Vollmer, H. (1939). Amer. F. Dis. Child. 57, 343.

Warkany, J. (1936). Amer. F. Dis. Child. 52, 831 .

Warkany, J. (1937). Biochem. Z. 293, 415.

Warkany, J., Guest, G. M. \& Grabill, F. J. (1942). F. Lab. clin. Med. 27, 557.

Warkany, J. \& Mabon, H. E. (1940). Amer. F. Dis. Child. 6o, 606.

\title{
Nutritional problems in the immigrant population in London
}

\author{
By C. Eric Stroud, King's College Hospital, London, S.E.5
}

During the past 10 years the immigrant population of this country has increased enormously. The three main countries of origin have been the West Indies, India and Pakistan. The immigrants largely settled in the big cities where they tended to aggregate in certain areas. In London, Brixton and Camberwell have a very high proportion of West Indian people. It is interesting to note that, although the number of immigrants entering this country has been greatly reduced as a result of the new immigration laws, the birth rate among those already here is very high. In Dulwich and St Giles Hospitals in London the number of West Indian babies born totalled over I000 last year and is increasing annually. It is obvious that the number of immigrant people in the big cities will continue to increase and their medical problems should therefore be well understood. A few of these problems are genetically determined, such as sickle cell anaemia and thalassaemia, but these diseases are uncommon. Much more important are the problems related to the adaptation which has to take place of these non-indigenous people to their new country.

West Indian children are occasionally seen in our hospital with minor skin changes suggestive of deficiencies of vitamin $A$ and the vitamins of the $B$ complex. These changes are nearly always very mild and disagreement arises as to whether or not they are significant. Of recent years however two nutritional diseases have been described amongst immigrant children, namely iron-deficiency anaemia and rickets. Both these diseases occur with a frequency and severity which leaves no doubt that they are an important aspect of the health of the children of the immigrant communities. Nearly all the affected children were born in this country of parents who had immigrated here. In November 1960 attention was drawn to the high incidence of iron-deficiency anaemia among West Indian children in the Camberwell and Brixton areas of London (Davis, Marten \& Sarkany, 1960). They investigated a total of I $_{4}$ infants whose ages ranged from 5 to 23 months and of whom forty-seven were West Indian and sixty-seven were European. One of their interesting findings was that the weights of these children showed no statistical difference but the haemoglobin levels of the West Indians were significantly lower at all ages than those 


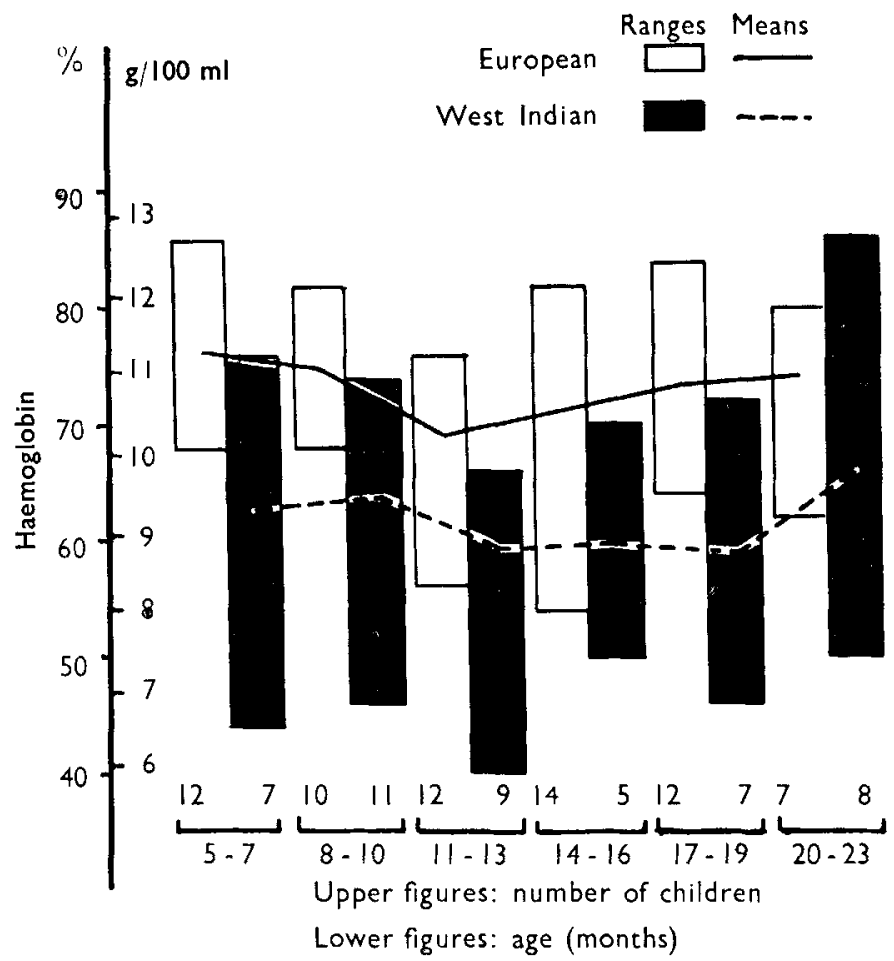

Fig. I. Comparison of haemoglobin mean values and ranges for English and West Indian infants living in London (from Davis et al. 1960). - - English infants; --- , West Indian infants. Boxed areas show ranges.

of the Europeans (see Fig. I). The mean corpuscular haemoglobin concentration was also lower at all ages in the West Indian children and the anaemia showed the characteristics of iron deficiency.

Of recent years we have been impressed by the frequent occurrence of rickets in the children's departments of two hospitals in the south of London. Recently we collected details of sixteen cases of nutritional rickets seen in Guy's and King's College paediatric departments (Benson, Stroud, Mitchell \& Nickolaides, I963). The number has now increased to nineteen. These were all the cases of nutritional rickets seen during the past 5 years. The number was surprisingly large, for most doctors were of the opinion that rickets was a disease of the past. The most interesting feature of the series was, however, that only one of the nineteen children was English, the other eighteen being children of immigrant parents as follows:- six West Indian, five Greek Cypriot, three Irish, one Nigerian, one Maltese, one Spanish and one with an Irish mother and West Indian father. All the children were born in London except for two, both of whom had lived in London for at least a year before rickets was diagnosed. There were twelve girls and seven boys and the ages at which they were first seen ranged from 9 to $3^{8}$ months. They all showed clinical and radiological evidence of rickets and on investigation the rickets was found to be active (see Table $\mathrm{r}$ ).

The nutritional aetiology was proved by the prompt healing which occurred in all cases on relatively small doses of vitamin $\mathrm{D}$. The dietary history, without exception, 
Table 1. Blood values for children with nutritional rickets living in London

\begin{tabular}{|c|c|c|c|c|c|c|c|}
\hline $\begin{array}{c}\text { Child } \\
\text { no. }\end{array}$ & Nationality & Sex & $\begin{array}{c}\text { Age at } \\
\text { onset } \\
\text { (months) }\end{array}$ & $\begin{array}{c}\text { Serum } \\
\text { calcium } \\
(\mathrm{mg} / 100 \mathrm{ml})\end{array}$ & $\begin{array}{c}\text { Serum } \\
\text { phosphate } \\
(\mathrm{mg} / \mathrm{i} 00 \mathrm{ml})\end{array}$ & $\begin{array}{c}\text { Serum } \\
\text { alkaline } \\
\text { phosphatase } \\
\text { (King-Armstrong } \\
\text { units/100 ml) }\end{array}$ & $\begin{array}{l}\text { Haemoglobin } \\
\text { (g/100 ml) }\end{array}$ \\
\hline I & West Indian & q & 19 & $8 \cdot 6$ & $I \cdot 9$ & I 84 & 10.2 \\
\hline 2 & West Indian & q & 21 & 9.0 & $\mathrm{I} \cdot 7$ & 125 & 9.5 \\
\hline 3 & West Indian & $\delta$ & 9 & $9 \cdot I$ & $3 \cdot 6$ & 55 & 9.0 \\
\hline 4 & West Indian & q & 10 & $9 \cdot 4$ & $4^{\prime} \cdot 1$ & 70 & $10 \cdot 3$ \\
\hline 5 & West Indian & $\delta$ & $3^{8}$ & $9 \cdot 3$ & $4 \cdot 2$ & 78 & 9.5 \\
\hline 6 & West Indian & 8 & 24 & $9 \cdot 3$ & $5 \cdot 2$ & $7 I$ & $12 \cdot 3$ \\
\hline 7 & Greek Cypriot & 우 & 19 & 10.8 & 4.5 & 46 & $6 \cdot 4$ \\
\hline 8 & Greek Cypriot & $q$ & 13 & $7 \cdot 6$ & $6 \cdot 8$ & 47 & 9.5 \\
\hline 9 & Greek Cypriot & q & 29 & 10.9 & $2 \cdot 5$ & 84 & $4=7$ \\
\hline 10 & Greek Cypriot & q & 15 & - & $3 \% 4$ & 37 & $12 \cdot 9$ \\
\hline I I & Greek Cypriot & 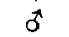 & 27 & $9 \cdot 7$ & $3 \cdot 2$ & I & $1+3$ \\
\hline 12 & Nigerian & 우 & 14 & $8 \cdot 4$ & $1 \cdot 8$ & 155 & $11 \cdot 2$ \\
\hline 13 & Irish & 0 & 26 & $9 \cdot 2$ & $3 \cdot 7$ & 71 & $14 \cdot 3$ \\
\hline 14 & Irish & $\hat{\sigma}$ & 12 & $9 \cdot 6$ & $2 \cdot 7$ & 73 & $I I \cdot I$ \\
\hline 15 & Irish & q & 18 & 9.4 & $5 * 4$ & $3 \mathrm{I}$ & $12 \cdot 3$ \\
\hline 16 & English & a & 30 & 9.2 & $3 \cdot 2$ & 75 & $9 \cdot 5$ \\
\hline 17 & Irish/West Indian & q & 24 & $9 \cdot 4$ & $2 \cdot I$ & 50 & II 4 \\
\hline I 8 & Maltese & 우 & 20 & $9 \cdot 3$ & $3 \cdot 4$ & 104 & $9 \cdot 3$ \\
\hline 19 & Spanish & 웅 & 16 & $8 \cdot 8$ & $2 \cdot 7$ & 58 & 10.2 \\
\hline
\end{tabular}

showed that these children had been breast fed or fed on cow's milk alone for a long period. None of them had been given supplementary vitamins and none of them had been fed on proprietary forms of dried milk which are fortified with vitamin $D$.

\section{Discussion}

With regard to the iron-deficiency anaemia, Davis et al. ( 1960 ) could give no reason why the West Indian children should be anaemic. They found 'no evidence to suggest that prematurity, excessive growth, malnutrition or the presence or absence of eczema was responsible' though they felt that the iron deficiency resulted from 'diminished iron stores at birth'. If this were true one would expect the West Indian mothers to show a higher incidence of anaemia than the European mothers. There is no evidence to show that it is so and the initial results of a survey to be carried out throughout pregnancy show that in early pregnancy there is no statistical difference in the haemoglobin levels of West Indian and European mothers in Camberwell (L. R. Davis, 1963, personal communication), though of course differences may appear in later pregnancy. What is obviously needed is a longitudinal study of the levels of haemoglobin, serum iron and iron-binding capacity in the mothers throughout pregnancy to be correlated with the same investigations in the relevant infants from birth throughout the first 2 years of life. My colleagues, Dr Davis and Dr Rawston, and I are in the process of carrying out such an investigation at present.

Eleven of the nineteen children with rickets had haemoglobin levels between 4.5 and $10.5 \mathrm{~g} / 100 \mathrm{ml}$. All of these children had been fed on breast or cow's milk for long periods. Davis et al. (I960) state that nutritional differences would not be likely to account for differences in the haemoglobin levels of infants at $5-7$ months. It is my 
experience that many European babies begin mixed feeding at about 3 months whereas the West Indian babies continue on an exclusively milk diet for much longer. It is possible therefore that the difference is entirely nutritional in origin and related to iron intake. Cow's milk contains only $0.2 \mathrm{mg}$ iron/100 $\mathrm{ml}$ and breast milk contains $0.02-0.35 \mathrm{mg} / 100 \mathrm{ml}$ (Morrison, I952). If a low iron store at birth is the reason for the early development of anaemia in the West Indian babies then prolonged milk feeding will certainly aggravate it.

When we come to consider the problem of rickets, the aetiology is much more obvious, but even so a number of factors must be considered. It is very tempting to quote the increased skin pigmentation of the immigrant children as the main cause of their rickets. In fact the Greek Cypriot children are not very deeply pigmented and, though rickets is not a rare disease among the children of immigrant peoples, the majority of children in London with deeply pigmented skin do not develop rickets. We must therefore look for other explanations. Rickets was found to be common amongst the Pakistani community of Glasgow with children aged from 5 to 15 years being most severely affected (Dunnigan, Paton, Haase, McNicol, Gardner \& Smith, I962). Of seventy-four adults and children examined thirty-five showed clinical or investigational evidence of rickets or osteomalacia. No evidence was found, however, in the fourteen children seen who were less than 5 years old. Dunnigan $e t$ al. suggested that 'welfare' foods had protected these children against rickets. In our series of nineteen children none that we were able to follow up were regular attenders at a welfare clinic and none of them were given vitamin supplements.

We formed the opinion that three factors are concerned in the production of rickets in these children.

Skin pigmentation. There is no doubt that adequate sunlight can compensate for lack of dietary vitamin D. Thus nutritional rickets is very rare in the West Indies (B. Symons, I 962, personal communication) even though the care of children in the first 2 years of life follows the same feeding pattern as that of the West Indian children in England. In Cyprus a paediatrician sees about ten to fifteen cases of rickets a year but these are mainly in the winter and among the children from mountainous cold districts where a lot of clothing has to be worn (C. Joannides, 1962, personal communication). In other parts of the tropics such as Africa there have been few.reports of rickets and these have been under 'peculiar and somewhat unusual circumstances' (Jelliffe, 1955). In England for a large part of the year there is little sunlight and the children have to be well covered with clothes. In the summer months the dark-skinned children are less able to benefit from the few months of sunshine because their pigment prevents deep penetration of u.v. light. This increased pigmentation is not, however, the most important aetiological factor, for supplementary vitamin D is readily available and rickets should not occur from lack of vitamin D if children are cared for properly.

Prolonged breast or cow's-milk feeding. 'The National and the proprietary forms of dried milk contain added vitamin $\mathrm{D}$ in such quantity that a child receiving 2 pints of milk daily will have an intake of at least 250 i.u. If a child is breast fed and 
taking 2 pints a day he will receive anything from 4 to roo i.u. and on two pints of cow's milk 3-45 i.u. vitamin D (Macy, Kelly \& Sloan, I953). In all the cases we described the children had been breast fed or fed for many months on cow's milk with no additional vitamin $\mathrm{D}$. This is obviously the major cause of their rickets.

Unsatisfactory attendance at welfare clinic. None of the children attended regularly at welfare clinics. The reasons were varied. The Greek Cypriot mothers had very marked language difficulties and some of them, in spite of having lived in England for years, could not speak English. As a result they understood instructions poorly and tended to lose enthusiasm. The West Indian mothers have many environmental social problems. Housing is more difficult and often more expensive than for English mothers. As part of a survey into the cause of burns in immigrant children, we have found that $51 \%$ of forty-three families questioned lived in one room and $35 \%$ in two rooms. Many mothers go out to work, sometimes because they are unmarried and have to support their children themselves. In such circumstances the children are cared for by 'child minders' some of whom are known and approved by the local authorities but many are 'unofficial' or are 'friends'. These child minders charge $25-30 \mathrm{~s}$. a week and many of the children are unable to go to the welfare clinic.

Although Davis et al. (1960) found no obvious weight difference between their European and West Indian children, we noted that in our children with rickets eight of the fourteen children who had been weighed were below the tenth percentile of average body-weights of English children (Tanner \& Whitehouse, 1959). Nearly all the children were born in this country and this figure does suggest that true protein-calorie malnutrition may exist in some social groups of the immigrant population.

It seems that in the production of these two nutritional disorders of anaemia and rickets it is in the cultural way of life and child rearing that the aetiology can be found. The same is of course true of many problems of malnutrition in underdeveloped countries (Jelliffe, I956) and the principle certainly seems to hold good for our own country.

There is an obvious need for research into the nutritional state of immigrant children and their mothers. There is also a need for research into ways in which the welfare clinics' cover of these children can be made more satisfactory, perhaps on lines such as have already been started by Dr Bruno Ganz who has organized evening welfare clinics for children whose mothers go out to work and who are cared for in the daytime by baby minders.

Such research, however, should not deal only with nutritional problems. Any of us who see many children of the immigrant communities know that in all fields of morbidity-infections, accidents in the home and especially burns-there is a much higher incidence amongst immigrant children than amongst English children and much of this morbidity is preventable.

\section{REFERENCES}

Benson, P. F., Stroud, C. E., Mitchell, N. \& Nickolaides, A. (1963). Brit. med. \%. i, 1054. Davis, L. R., Marten, R. H. \& Sarkany, I. (1960). Brit. med. Y. ii, 1426. 
Dunnigan, M. G., Paton, J. P. J., Haase, S., McNicol, G. W., Gardner, M. D. \& Smith, C. M. (Ig62). Scot. med. F. 7, 159 .

Jelliffe, D. B. (I955). World Hlth Org. Monogr. Ser. no. 29.

Jelliffe, D. B. (I956). F. Pediat. 49, 66.

Macy, I. C., Kelly, H. J. \& Sloan, R. E. (1953). Publ. nat. Res. Coun., Wash., no. 254.

Morrison, S. D. (1952). Tech. Commun. Bur. Anim. Nutr., Aberd., no. 18.

Tanner, J. M. \& Whitehouse, R. (1959). Height and Weight Standard Charts. London: Joseph Collard and Sons. 